\title{
ANALISIS KEDUDUKAN ADAT DALAM HUKUM WARIS ISLAM DAN HINDU BESERTA IMPLIKASINYA
}

\author{
Zakiyatul Ulya \\ Fakultas Syari'ah dan Hukum UIN Sunan Ampel Surabaya. E-mail: \\ ulyaelzakiyah@gmail.com
}

\begin{abstract}
Tradition/'urf is recognized by Islamic law as a legal basis with several conditions. While the use of tradition in the distribution of inheritance is not justified because it is contrary to the provisions of Islamic inheritance which are qat'iyah aldilalah and qat'iyah al-wurud. The distribution based on tradition that can be done with the agreement of the heirs, after knowing their respective parts and no one is harmed, as in article 183 of KHI. Tradition in Hindu is recognized as a source of law, which becomes law and also applies as a law with conditions that are appropriate with atmavan. The position of tradition in inheritance law has been recognized and legalized its enforcement in an area, varna, company or village based on Sloka 40 parts 60 chapter 7, Artas\#astra book. Both Islamic and Hindu laws create tradition as the basis for law enforcement. The use of tradition in the distribution of inheritance is not justified by Islam because of it contradicts with Syara' argument. However, the distribution based on tradition can be done with the agreement of the heirs, according to article 183 of KHI. In contrast, Hindu law legalizes customary enforcement in an area, varna, company or village as inheritance law based on Sloka 40 parts 60 chapter 7 , Artas\#astra book.
\end{abstract}

Key words: Tradition, Islamic Inheritance Laws, Hindu Inheritance Laws.

Abstrak: Adat/'urf diakui oleh hukum Islam sebagai landasan hukum dengan beberapa persyaratan. Adapun penggunaan adat dalam pembagian harta waris tidak dibenarkan karena bertentangan dengan ketentuan kewarisan Islam yang bersifat qat'iyah al-dilalah dan qat'iyah al-wurud. Akan tetapi, pembagian berdasarkan adat dapat dilakukan dengan kesepakatan ahli waris, setelah mengetahui bagiannya masing-masing serta tidak ada yang dirugikan, sebagaimana pasal 183 KHI. Adat dalam agama Hindu diakui sebagai sumber hukum, yang menjadi hukum dan juga berlaku sebagai hukum dengan syarat selaras dengan atmavan. Adapun kedudukan adat dalam hukum waris telah diakui dan dilegalkan pemberlakuannya pada suatu daerah, varna, perusahaan atau desa berdasarkan Sloka 40 Bagian 60 Bab 7 Kitab Artas\#astra. Baik hukum Islam maupun hukum Hindu sama-sama menjadikan adat sebagai landasan dalam penetapan hukum. Penggunaan adat dalam pembagian harta waris tidak dibenarkan oleh agama Islam karena bertentangan dengan dalil syara'. Akan tetapi, pembagian berdasarkan adat dapat dilakukan dengan adanya kesepakatan

AL-HUKAMA

The Indonesian Journal of Islamic Family Law Volume 09, Nomor 01, Juni 2019; ISSN:2089-7480 
ahli waris, sesuai pasal 183 KHI. Berbeda halnya dengan hukum Islam, hukum Hindu melegalkan pemberlakuan adat pada suatu daerah, varna, perusahaan atau desa sebagai hukum kewarisan berdasarkan Sloka 40 Bagian 60 Bab 7 Kitab Artas\#astra.

Kata Kunci: adat, hukum waris Islam, hukum waris Hindu.

\section{Pendahuluan}

Kelahiran dan kematian merupakan dua peristiwa yang pasti akan dilewati oleh manusia. Keduanya akan menimbulkan akibat hukum masing-masing. Peristiwa kelahiran akan menimbulkan hubungan hukum dengan masyarakat sekitar, yang berdampak pada munculnya hak dan kewajiban pada dirinya. Begitu juga peristiwa kematian yang bersifat personal akan berakibat hukum pada orang lain, khususnya kepada keluarganya dan beberapa pihak lain yang memiliki hubungan dengan orang tersebut semasa masih hidupnya. Hal ini tergambarkan pada permasalahan kewarisan yang akan berakibat pada beralihnya harta orang yang meninggal kepada pihak lain yang masih hidup dan memiliki salah satu penyebab untuk mendapatkan harta warisan serta bebas dari halangan pewarisan.1

Sistem hukum yang berlaku di Indonesia merupakan campuran dari sistem hukum adat, hukum agama dan hukum Eropa, yang masing-masing dari ketiganya menyatakan bahwa semua orang yang terikat dengan hukum tersebut harus mengikuti dan mematuhi otoritasnya, bahkan mereka juga harus mengakui hukum tersebut mengikat bagi mereka, meskipun adanya pelanggaran yang dilakukan oleh merika terhadap hukum yang dimaksud.2 Hukum adat dianut bahkan diserap dalam perundang-undangan dan yurisprudensi karena merupakan aturan masyarakat setempat dan telah membudaya di wilayah nusantara; hukum agama, khususnya hukum agama Islam, dianut karena masuknya beberapa agama di Indonesia yang akhirnya memberikan pedoman/pemahaman baru bagi masyarakat baik di bidang perkawinan maupun kewarisan; hukum Eropa, khususnya dari Belanda, baik yang berkenaan dengan hukum perdata maupun pidana, dianut oleh masyarakat Indonesi

1 Suparman Usman dan Yusuf Somawinata, Fiqib Mawaris Hukum; Kewarisan Islam (Jakarta: Gaya Media Pratama, 2002), 13.

2 Bambang Subandi, et. al., Studi Hukum Islam (Surabaya: IAIN SA Press, 2011), 155.

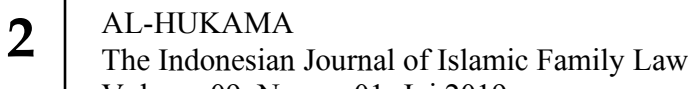
Volume 09, Nomor 01, Jui 2019
} 
karena aspek sejarah Indonesia yang merupakan wilayah jajahan Hindia-Belanda (Nederlandsch-Indie).3

Oleh karena beragamnya, sistem hukum yang berlaku di Indonesia di atas, ditambah lagi tidak ter-cover-nya ketiga sistem tersebut dalam hukum negara secara utuh, maka dalam kehidupan sehari-harinya masyarakat sering dihadapkan dengan pilihan-pilihan yang berkaitan dengan sistem hukum yang akan digunakan dalam menyelesaikan permasalahan yang dihadapinya, apakah harus menggunakan hukum adat, agama atau Eropa. Adapun dalam persoalan kewarisan sendiri, sistem hukum yang paling sering digunakan adalah sistem hukum adat dan hukum agama serta jarang diselesaikan dengan menggunakan hukum negara (Eropa), karena kewarisan merupakan persoalan yang bersifat privat dan intern dalam keluarga.

Di Indonesia terdapat enam agama resmi yang diakui oleh negara, yaitu: Islam, Katholik, Protestan, Hindu, Budha dan Konghuchu, 4 yang keenamnya mempunyai aturan agama masingmasing, termasuk dalam persoalan kewarisan. Dalam kesehariannya, tidak jarang pemeluk dari agama-agama tersebut hidup secara damai dan berdampingan pada wilayah yang sama, sebagai contohnya adalah wilayah Sidoarjo yang dihuni oleh masyarakat yang memiliki latar belakang keagamaan yang berbeda. Adapun jika berbicara mengenai persinggungan hukum adat dengan hukum agama, menjadi menarik jika menyandingakan adat Adapun ketika berbicara mengenai persinggungan hukum adat dengan hukum agama, menjadi lebih menarik jika menyandingan hukum agama Hindu yang menurut sejarahnya telah memberikan pengaruh kepercayaan dan kebudayaan Jawa di Indonesia dengan hukum agama Islam yang

3 Wikipedia; Ensiklopedi Bebas, "Hukum Indonesia", dalam http://id.wikipedia.org/wiki/Hukum Indonesia, diakses pada 17 Januari 2018. 4 Abdurrahman, "6 Agama yang Diakui Secara Resmi oleh Negara Republik Indonesia", dalam http://baharudinwahida.blogdetik.com/index.php/2012/10/25/6-agama-yangdiakui-secara-resmi-oleh-negara-republik-indonesia/, diakses pada 17 Januari 2018. 
notabene-nya merupakan dasar bagi agama yang dianut oleh mayoritas masyarakat di Indonesia.5

Hukum Islam dan hukum Hindu telah mengatur secara rinci segala persoalan yang berhubungan dengan kewarisan, baik mengenai pengertian dan asas/unsur kewarisan, rukun dan syarat kewarisan, sebab-sebab mendapatkan dan menghalangi untuk kewarisan, penggolongan ahli waris dan bagiannya masing-masing, serta tata cara pembagian harta warisan. Antara keduanya tentu memiliki persamaan dan perbedaan dalam ketentuan-ketentuannya tersebut.6 Hukum kewarisan Islam sering diartikan sebagai seperangkat aturan tertulis yang berdasarkan wahyu Allah dan sunnah Nabi mengenai peralihan/perpindahan harta milik orang yang meninggal kepada ahli waris yang berhak menerima harta tersebut, yang diyakini dan diakui mengikat dan berlaku untuk semua orang yang beragama Islam.7 Senadan dengan definisi tersebut, hukum kewarisan Hindu diartikan oleh A. Pitolo sebagai kumpulan peraturan mengenai pemindahan/peralihan harta kekayaan yang ditinggalkan oleh orang yang meninggal kepada ahli waris yang berhak, beserta akibat yang ditimbulkan dalam hubungan antara ahli waris maupun antara ahli waris dengan pihak ketiga.8

Meskipun hukum kewarisan Islam maupun hukum kewarisan Hindu telah mengatur secara lengap berbagai persoalan mengenai waris sebagaimana yang tergambar dalam pemaparan singkat di atas, namun dalam realitanya, tidak semua ketentuan-ketentuan tersebut ditaati dan dipatuhi oleh pemeluk kedua agama tersebut. Keduanya lebih sering memilih untuk menggunakan hukum adat dibandingkan dengan hukum agama dalam menyelesaikan segala permasalahan kewarisan yang dihadapinya dengan berbagai alasan, yang salah

\footnotetext{
5 Wikipedia, "Agama Hindu Jawa", dalam https://id.m.wikipedia.org/wiki/Agama_Hindu_Jawa, diakses pada 19 Januari 2018.

6 Baghavan Bhrgu, Manava Dharmasastra, terj. G. Pudja dan Tjokorda Rai Sudharta (Surabaya: Paramita, 2004), 484.

7 Amir Syarifuddin, Hukum Kewarisan Islam (Jakarta: Kencana, 2004), 5-6.

8 Hukum Hindu, "Hukum Waris Hindu Berdasarkan Arthasastra", dalam http://hukumhindu.blog.com/2011/06/25/hukum-waris-hindu-berdasarkanarthasastra/, diakses pada 19 Januari 2018.
} 
satunya adalah hukum adat dirasa lebih adil dalam menentukan porsi harta warisan untuk masing-masing ahli waris yang berhak menerimanya, sehingga dapat mencegah perselisihan antar ahli waris.

Lantas bagaimana realita di atas jika dikaji dari perspektif hukum masing-masing. Apakah praktik pembagian warisan yang berpedoman pada hukum adat itu dilegalkan/dibolehkan oleh hukum Islam dan hukum Hindu atau bahkan sebaliknya, beserta implikasinya masing-masing. Berangkat dari permasalahan tersebut, maka menjadi menarik untuk melakukan sebuah penelitian lanjutan dengan judul Kedudukan Adat dalam Hukum Waris Islam dan Hindu Beserta Implikasinya dengan tujuan untuk mendapatkan kesimpulan yang utuh mengenai kedudukan adat, baik dalam hukum Islam maupun hukum Hindu, sehingga dapat diketahui tentang boleh tidaknya praktik pembagian warisan yang berpedoman pada hukum adat tesebut dilakukan beserta implikasinya, yang kemudian akan dilanjutkan dengan memperbandingkan keduanya.

\section{Kewarisan dalam Hukum Islam}

Waris dalam Islam dapat didefinisikan sebagai perpindahan/peralihan harta warisan, baik berwujud harta maupun hak lainnya, dari orang yang meninggal/pewaris kepada orang yang berhak mewarisi harta tersebut/ahli waris.9 Adapun asas yang menjadi dasar proses pewarisan dalam Islam adalah:

1. Asas ketauhidan/ketuhanan, yang artinya bahwa pembagian harta warisan harus didasarkan pada keimanan yang kuat kepada Allah dan Rasulnya dengan bersumber pada al-Qur'an dan hadis. 10

2. Asas ijbari, yang berarti bahwa perpindahan harta warisan terjadi dengan sendirinya tanpa adanya usaha atau kehendak, baik dari ahli waris maupun pewaris. Ketentuan mengenai untuk siapa harta warisan tersebut dan berapa jumlah yang akan

9 Abdur Rahman I. Doi, Syariah The Islamic Law, terj. Zaimuddin, et al., cet. 1 (Jakarta: PT. Raja Gravindo Persada, 1996), 98.

10 Beni Ahmad Saebani, Figh Mawaris, cet. 3 (Bandung Pustaka Setia, 2015), 1920. 
didapatkan serta bagimana proses pembagiannya tidak dapat dirubah.

3. Asas bilateral yang artinya bahwa ahli waris akan menerima harta warisan dari kedua belah pihak kerabat, baik dari garis kerabat laki-laki maupun perempuan serta berlaku garis kerabat menyamping.11

4. Asas semata akibat kematian, yang berarti bahwa proses kewarisan hanya berlaku setelah pewaris meninggal, sehingga perpindahan harta yang dilakukan seseorang sebelum meninggal dunia tidak bisa disebut dengan waris. 12

5. Asas individual, yang artinya bahwa ahli waris berhak menerima harta warisan sesuai dengan kadar bagian yang telah ditentukan, secara perseorang, baik laki-laki maupun perempuan tanpa adanya pengecualian. 13

6. Asas keadilan berimbang, yang artinya bahwa adanya keseimbangan antara hak yang akan diperoleh, berupa bagian harta warisan dengan kewajiban/bagian yang akan ditanggung. Dalam hal ini, ahli waris laki-laki menerima bagian lebih banyak daripada perempuan karena mempunyai kewajiban untuk menafkai keluarganya di samping menafkai dirinya sendiri.14

Ada beberapa rukun yang ada dalam kewarisan, yaitu:

1. Pewaris/muwarrith (orang yang meninggal dunia dan hartanya akan diwariskan kepada ahli waris);

2. Ahli waris/warith (orang yang akan mewarisi harta warisan);

3. Harta warisan/mauruth (harta yang menjadi warisan, baik berbentuk benda maupun hak). 15

11 Amir Syarifuddin, Hukum Kewarisan Islam..., 17-18.

12 Darmawan, Hukum Kewarisan Islam di Indonesia (Surabaya: UIN Sunan Ampel Press, 2014), 82.

13 Naskur, "Asas-asas Hukum Kewarisan dalam Islam (Studi Analisis Pendekatan Al-Qur'an dan Al-Hadis Sebagai Sumber Hukum Islam)”, Al-Syir'ah, No. 2, Vol. 10 (2012).

14 Maryati Bachtiar, "Hukum Waris Islam di Pandang dari Perspektif Hukum Berkeadilan Gender”, Jurnal Ilmu Hukum, No. 1, Vol. 3 (2012).

15 Komite Fakultas Syariah Uiniversitas Al-Azhar, Abkam al-Mawarith fi al-Fiqh alIslami, terj. Addys Aldizar dan Fathurrahman, cet. 15 (Jakarta Selatan: Senayan Abadi Publishing, 2015), 27-28.

\footnotetext{
\begin{tabular}{l|l}
6 & $\begin{array}{l}\text { AL-HUKAMA } \\
\text { The Indonesian Journal of Islamic Family Law } \\
\text { Volume 09, Nomor 01, Jui } 2019\end{array}$
\end{tabular}
} 
Dari ketiga rukun tersebut harus dipenuhi beberapa persyaratan di bawah ini:

1. Kematian pewaris/muwarrith, yang meliputi mati haqiqi, mati bukmi dan taqdiri;

2. Hidupnya ahli wars/warith saat meninggalnya pewaris / muwarrith;16

3. Adanya salah satu penyebab mewarisi, yang berupa adanya ikatan nasab/kekerabatan hakiki, terjadinya pernikahan yang sah dan masih utuh,17 pemerdekaan budak (wala' al-'itgi) 18 dan representasi Islam.19

4. Tidak adanya penghalang kewarisan,20 yang terbagi menjadi dua, yaitu:

a. Mahrum/adanya halangan kewarisan, yang berupa pembunuhan,21 perbudakan, dan perbedaan agama.22

b. Mabjub/adanya kelompok utama, yang dapat menghilangkan hak kewarisan ahli waris, baik sebagian (bijab nuqsan) maupun seluruhnya (bijab birman).23

Adapun golongan ahli waris yang disepakati jumhur ulama berjumlah dua puluh lima orang, dengan rincian sebagai berikut:

1. Golongan ahli waris laki-laki, yang terdiri dari anak laki-laki, cucu laki-laki dari garis keturunan laki-laki dan seterusnya ke bawah; bapak, kakek dan seterusnya ke atas; saudara laki-laki sekandung, sebapak, seibu; anak laki-laki saudara laki-laki sekandung, sebapak; paman sekandung, sebapak; anak laki-laki

16 Moh. Muhibbin dan Abdul Wahid, Hukum Kewarisan Islam: Sebagai Pembaharuan Hukum Positif di Indonesia (Jakarta: Sinar Grafika, 2009), 62.

17 Al-Sayyid Sabiq, Fiqh al-Sunnah, terj, Mudzakir (Bandung: PT Alma'arif, 1987), 258-259.

18 M. 'Ali al-Sabuni, Al-Mawarith fi ash-Shari'ati al-Islamiyah 'ala Dhaw' al-Kitab wa al-Sunnah, terj. A. M. Basamalah, cet. 1 (Jakarta: Gema Insani Press, 1995), 39.

19 Wahbah al-Zuhaili, Fiqh al-Islam wa Adillatuhu, terj. Abdul Hayyie al-Kattani, et. al. (Jakarta: Gema Insani, 2011), 348-349.

20 Darmawan, Hukum Kewarisan Islam di Indonesia..., 33-34.

21 Amir Syarifudin, Hukum Kewarisan Islam..., 197.

22 Wahbah al-Zuhaili, Fiqh al-Islam wa Adillatubu..., 354.

23 M. 'Ali al-Sabuni, Al-Mawarith fi ash-Shari'ati al-Islamiyah 'ala dhaw' al-Kitab wa alSunnah..., 44. 
paman sekandung, sebapak; suami; dan orang laki-laki yang memerdekakan budak.

2. Golongan ahli waris perempuan, yang terdiri dari anak perempuan, cucu perempuan dari garis keturunan laki-laki dan seterusnya ke bawah; ibu, nenek dari pihak ibu dan seterusnya ke atas, dari pihak bapak dan seterusnya ke atas; saudara perempuan sekandung, sebapak, seibu; istri; audara perempuan sekandung, sebapak, seibu; istri; dan orang perempuan yang memerdekakan budak.24

Dari kedua puluh lima golongan ahli waris yang telah disebutkan di atas, dapat dikatagorikan lagi menjadi tiga kelompok, yaitu:

1. Ashab al-furud, yaitu kelompok ahli waris yang bagiannya telah ditentukan oleh syara'25 $(2 / 3,1 / 3,1 / 6,1 / 2,1 / 4$ dan 1/8),26 terdiri dari anak perempuan (1/2 atau $2 / 3)$; cucu perempuan dari garis keturunan laki-laki seterusnya ke bawah $(1 / 2,2 / 3$ atau 1/6); ibu (1/6,1/3 atau 1/3 dari sisa); bapak, kakek (1/6 atau $1 / 6$ dan selanjutnya mengambil sisa harta); nenek (1/6); saudara perempuan sekandung (1/2 atau 2/3); saudara perempuan sebapak (1/2, 2/3 atau $1 / 6)$; suami $(1 / 2$ atau $1 / 4)$; istri $(1 / 4$ atau $1 / 8) ; 27$ saudara laki-laki seibu, saudara perempuan sebapak $(1 / 6$ atau $1 / 3) .28$

2. 'Asabah, yaitu kelompok ahli waris yang tidak mempunyai bagian tertentu dan akan mendapatkan bagian sisa dari harta warisan setelah diambil kelompok ashab al-furud,29 yang terdiri dari:

a. 'Asabah nasabiyah, yaitu kelompok yang menjadi asabah karena adanya hubungan darah, meliputi: 'asabab binafsib (menjadi 'asabah karena kedudukannya sendiri), 'asabah bi al-ghair (menjadi asabah karena orang lain) dan 'asabab ma'a

24 Ahmad 'Abd al-Jawad, Usul; Tlm al-Mawarith (Beirut: Dar al-Jil, 1986), 4.

25 Suparman Usman dan Yusuf Somawina, Fiqih Mawaris; Hukum Kewarisan Islam..., 66.

26 Fatkhur Rahman, Ilmu Waris (Bandung: Al-Ma'arif, 1974), 128.

27 Amir Syarifuddin, Hukum Kewarisan Islam, 225-229.

28 Ibid., 228.

29 Suparman Usman dan Yusuf Somawina, Fiqih Mawaris..., 65.

$8 \begin{aligned} & \text { AL-HUKAMA } \\ & \text { The Indonesian Journal of Islamic Family Law } \\ & \text { Volume 09, Nomor 01, Jui } 2019\end{aligned}$ 
al-ghair (menjadi 'asabab karena mewarisi bersama golongan ahli waris lain);

b. 'Asabah sababiyah, yaitu menjadi 'asabah karena adanya sebab, yaitu pemerdekaan budak.30

3. Dhaw al-arbam, yaitu kelompok ahli waris yang bukan termasuk pada golongan ashab al-furud maupun 'asabah.

Sebelum dilaksanakan pembagian harta warisan kepada ahli waris yang berhak, ada hal-hal yang harus ditunaikan terlebih dahulu atas harta peninggalan, yaitu berupa pelunasan hutang pewaris,31 pembiayaan pengurusan jenazah 32 dan pelaksanaan wasiat pewaris. 33 Setelah bagian telah bersih dari hutang, biaya pengurusan jenazah dan wasiat, dibagikan kepada ahli waris yang berhak, dimulai dari kelompok ashab al-furud, kemudian kelompok 'asabah jika ada bagian sisa, dan dhaw al-arbam di urutan terakhir jika tidak ada kelompok ashab al-furud maupun 'asabah. 34

Dari penjelasan di atas, dapat diketahui bahwa hukum waris Islam telah mengatur persoalan waris secara jelas dan rinci, mulai dari pengertian, asas kewarisan Islam, rukun dan syarat, penyebab dan penghalang untuk mendapatkan harta warisan, golongan ahli waris beserta bagiannya masing-masing sampai pada tahap bagaimana tata cara pembagian harta warisnya, yang semuanya didasarkan pada ayat al-Qur'an dan Hadis serta ditambah dengan ijtihad para ulama terhadap kedua sumber utama tersebut.

\section{Kewarisan dalam Hukum Hindu}

Waris dalam agama Hindu didefinisikan sebagai pemindahan harta kekayaan pewaris kepada ahli waris akibat kematian, baik yang berbentuk materiil maupun immateriil beserta akibatnya, dalam hubungan antar ahli waris maupun antara ahli waris dengan pihak

30 Suhrawardi K. Lubis, et al, Hukum Waris Islam: Lengkap \& Praktik, cet. 3 (Jakarta: Sinar Grafika, 2008), 99-101.

31 Azyumardi Azra, et al., "Waris", Ensiklopedi Islam, Vol. 5, ed. Abdul Aziz Dahlan, et al. (Jakarta: PT Ikrar Mandiriabadi, 2000), 192.

32 Darmawan, Hukum Kewarisan Islam di Indonesia..., 110.

33 Abdul Manan, Aneka Masalah Hukum Perdata di Indonesia, cet. 3 (Jakarta: Kencana, 2012), 216.

34 Fatkhur Rahman, Imu Waris..., 131. 
ketiga.35 Adapun asas yang mendasari pelaksanaan warisnya adalah sebagai berikut:

1. Akibat kematian orang tua, yang berarti harta warisan baru akan berpindah ketika orang tuanya meninggal.

2. Pengutamaan keturunan laki-laki karena mempunyai keistimewaan dibanding keturunan perempuan.

3. Harta warisan boleh dibagi secara individual atau dimiliki secara bersama dengan adanya penanggugjawab.

4. Pewarisan setiap golongan secara bergantian, bukan bersaman. 36

Dalam kewarisan Hindu, terdapat beberapa unsur yang harus ada pada setiap pelaksanaan kewarisan adalah:

1. Orang yang meninggalkan harta warisan (pewaris).

2. Orang yang berhak menerima warisan (ahli waris).

3. Harta peninggalan pewaris (harta warisan)

dengan syarat meninggalnya pewaris, masih hidupnya ahli waris ketika pewaris meninggal, adanya penyebab mewarisi dan tidak adanya penghalang untuk mendapatkan harta warisan.37

Adapun seseorang berhak mendapatkan harta warisan jika adanya hubungan kekeluargaan/sedarah/sapinda,38 pengangkatan status anak perempuan menjadi anak laki-laki/putrika,39 pengangkatan anak/adopsi,40 hubungan guru dan murid,41 dan berkedudukan sebagai raja/brabm|ana.42 Akan tetapi, tidak selamanya ahli waris yang berhak mewarisi tersebut akan selalu dapat mewarisi, karena ada beberapa halangan pewarisan yang menyebabkan hilangnya sebagian harta warisan meliputi: tidak

35 Hukum Hindu, "Hukum Waris Hindu Berdasarkan Arthasastra".

36 Niscaya Bali, "Rangkuman Kitab Manawa Dharma Sastra", dalam http://niscayabali.net/rangkuman-kitab-manawa-dharma-sastra/, diakses pada 22 Oktober 2018.

37 Yuni Wulandari, "Studi Komparasi Tentang Ketentuan Ahli Waris dalam Hukum Islam dan Hindu” (Skripsi--IAIN Sunan Ampel, Surabaya, 2012), 7-9.

38 Baghavan Bhrgu, Manava Dharmasastra..., 484.

39 Ibid., 469-471.

40 Ibid., 473.

41 Kautilya (Canakya), Artas\#astra..., 241.

42 Ibid., 238. 
adanya sifat jantan, 43 melepaskan kewajiban beragama/berkelakuan tidak benar,44 dan penipuan terhadap ahli waris karena keserakahan;45 serta yang menyebabkan hilangnya seluruh bagian harta warisan meliputi: memiliki kelainan, penyakit tertentu/tidak sempurna inderanya,46 dan biasa melakukan pekerjaan yang terlarang. 47

Ahli waris dalam hukum kewarisan Hindu digolongkan menjadi beberapa kelompok, yaitu: kelompok I (anak), kelompok II (cucu dan cicit), kelompok III (janda), kelompok IV (saudara), kelompok $\mathrm{V}$ (orang tua), yang ditambah dengan guru/murid dan raja/brahmana. Selanjutnya kelompok tersebut digolongkan menjadi: sapinda (keluarga yang mempunyai hubungan darah dengan pewaris ke atas dan ke bawah tiga tingkat), anantara sapinda (golongan terdekat dengan ketiga golongan sapinda) dan sakulya (anggota keluarga yang dekat dan tidak harus sedarah).48

Adapun bagian yang didapatkan adalah anak laki-laki (Seluruh harta warisa49, berbagi sama setelah dikurangi bagian tambahan anak laki-laki sulung $(1$ 1/2: 1$) \mathbf{5 0}, 1 / 3$ atau $1 / 4$ dari bagian normal (1 1/2) yang seharusnya didapatkan oleh anak laki-laki sulung),51 putrika (sama dengan bagian anak sah52 atau dengan bagian anak laki-laki yang lahir setelah adanya pengangkatan),53 anak angkat (seluruh harta warisan54 atau sama dengan bagian anak sah). 55

43 Ibid., 465.

44 Ibid., 240.

45 Baghavan Bhrgu, Manava Dharmasastra..., 491.

46 Ibid., 488.

47 Ibid., 491.

48 Ibid., 484.

49 Ibid., 464.

50 Ibid., 466-467.

51 Kautilya (Canakya), Artas\#astra..., 240.

52 Ibid., 242.

53 Baghavan Bhrgu, Manava Dharmasastra..., 469-471.

54 Ibid., 467-468.

55 Kautilya (Canakya), Artas\#astra, terj. Made Astana dan Anomdiputro (Surabaya:

Paramita, 2003), 243. 
Sebelum harta pewaris dibagikan kepada ahli waris yang berhak, terlebih dahuli harus diambil untuk melunasi hutang-hutang yang ditinggalkan oleh pewaris.56 Adapun dalam kitab Manava Dharmas^astra, golongan sapinda, anantara sapinda dan sakulya mewarisi secara bergantian, dimulai dari sapinda, lalu anantara sapinda dan sakulya pada urutan terakhir (dimulai dari putra aurasa dan ksetraja serta anak angkat, putrika, $\mathbf{5 7}$ janda, anak perempuan yang belum menikah, ayah dan ibu, saudara/putranya, kakek/nenek, semua yang dekat dengan sapinda, keluarga, guru/murid dan raja/brahmana pada urutan terakhir).58

Adapun urutan pembagian harta waris tersebut dijelaskan secara lebih ringkas dalam kitab Artas\#astra, yaitu dimulai dari anak, ayah, saudara laki-laki dan anak laki-lakinya, guru/murid serta raja/brahmana pada urutan terakhir.59 Dalam pembagian harta warisan, agama Hindu mensyaratkan adanya para saksi, dan apabila terjadi kesalahan dalam pembagiannya, maka dapat dilakukan pembagian ulang.60

Dari penjelasan di atas, dapat diketahui bahwa agama Hindu juga telah mengatur secara rinci persoalan waris, yaitu mulai pengertian, asas kewarisan Hindu, unsur dan syarat, penyebab dan penghalang untuk mendapatkan harta warisan, golongan ahli waris beserta bagiannya masing-masing sampai pada tahap bagaimana tata cara pembagian harta warisnya, yang semua didasakan pada slokasloka dalam kitab Hindu, baik dalam kitab Manawa Dharmas astra maupun kitab Arthas\#astra.

\section{Analisis Kedudukan Adat dalam Hukum Waris Islam Beserta Implikasinya}

Jika diteliti lebih jauh, ketentuan-ketentuan nash yang dijadikan dasar kewarisan Islam harus diterima dan diamalkan secara tekstualis serta tidak terganggu oleh ijtihad para ulama karena bersifat qat'iyah al-dilalah (yang pasti artinya). Ketentuan nash yang dimaksud

56 Ibid., 492.

57 Ibid., 477-478.

58 Ibid., 485.

59 Kautilya (Canakya), Artas\#astra..., 237-238.

60 Ibid., 238. 
mempunyai sifat tersebut salah satunya karena berupa lafal mubkam yaitu lafal yang artinya dapat diketahui dengan jelas dan kuat dengan sendirinya tanpa ditakwilkan karena susunan tertibnya tepat dan tidak ada kemusykilan, sehingga dapat diamalkan dengan mudah. Ciri-cirinya adalah:

1. Jelas petunjuknya dan tidak mungkin telah di-nasakh (dihapuskan hukumnya).

2. Tidak bisa ditakwilkan kecuali dari satu arah atau satu segi saja.

3. Bisa berdiri sendiri atau telah jelas dengan sendirinya tanpa membutuhkan keterangan lainnya.

4. Tepat susunan dan rangkaiannya, sehingga mudah dipahami maksudnya.

5. Jelas maknanya, sehingga tidak mengakibatkan kemusykilan atau kesulitan arti.61

Selain itu juga bersifat qat'iyah al-wurud karena berasal dari sumber yang benar, yaitu al-Qur'an dan hadis mutawatir.

Hal ini sesuai dengan asas ijbari dalam hukum kewarisan Islam, yaitu perpindahan harta warisan terjadi dengan sendirinya tanpa adanya usaha atau kehendak dari pewaris maupun ahli waris, baik dari segi siapa yang menerima, jumlah yang akan diterima beserta tata cara pembagiannya telah diatur secara rinci oleh syara'.62 Meskipun begitu, tetap saja beberapa orang dalam suatu masyarakat lebih memilih untuk berpedoman dengan adat yang berlaku di daerahnya masing-masing.

Adat atau 'urf merupakan suatu perkataan maupun perbuatan yang dikenal oleh manusia dan telah menjadi kebiasaan mereka. Kebiasaan tersebut yang akan menjadi pertimbangan dalam menetapkan hukum terhadap berbagai permasalahan yang hukumnya tidak secara tegas diungkapkan dalam al-Qur'an dan hadis.63 Dalam hal ini, 'urf/adat merupakan salah satu dalil yang tidak disepakati oleh ulama (mukbtalaf), di samping istihsan, maslabah mursalah, 'urf, istishab, shar'u man qablana, madhab al-sababi, dan sadd al-

61 Achmad Zuhdi, Studi al-Qur'an, cet. 6 (Surabaya: UIN Sunan Ampel Press, 2016), 365.

62 Amir Syarifuddin, Hukum Kewarisan Islam..., 17-18.

63 Satria Effendi, Ushul Fiqh, 153-154. 
dhari'ah, berbeda dengan al-Qur'an, hadis, ijma' dan qiyas yang merupakan dalil yang disepakati oleh ulama (muttafaq).64

Al-Qur'an merupakan kalam Allah yang diturunkan kepada Nabi Muhammad saw. melalui perantara malaikat Jibril dengan bahasa Arab serta dianggab sebagai ibadah jika membacanya; hadis merupakan segala perilaku Rasulullah saw. yang berhubungan dengan hukum;65 ijma' merupakan kesepakatan semua mujtahid pada suatu masa setelah wafatnya Rasulullah saw. terhadap hukum syara' mengenai suatu kasus tertentu; qiyas merupakan suatu perkara yang tidak ada hukumnya dalam nas dengan perkara yang ada nas hukumnya karena adanya persamaan 'illat.

Istihsan merupakan perpindahan seorang mujtahid dari qiyas jali kepada qiyas khafi karena adanya dalil yang membenarkannya;66 maslahah mursalah merupakan sesuatu yang dianggap maslahat namun tidak ditetapkan dan ditolak oleh nash; 'istishab merupakan penetapan berlakunya suatu hukum yang telah ada sampai ada bukti yang mengubah kedudukannya; shar'u man qablana merupakan syari'at atau ajaran nabi-nabi sebelumnya yang berhubungan dengan hukum; madhab al-sahabi merupakan pendapat sahabat Rasulullah saw. mengenai hukum suatu kasus yang tidak dijelaskan secara tegas dalam nash; dan sadd al-dhariah merupakan penutupan jalan yang membawa kepada kebinasaan/kejahatan.

Para ulama sepakat menolak 'urf fasid untuk dijadikan sebagai landasan hukum, sedangkan mengenai 'urf sahih, mayoritas ulama telah sepakat untuk memeliharanya dalam pembentukan hukum, meskipun dengan jumlah dan rincian yang berbeda.67 Urf shahih merupakan sesuatu yang telah dikenal manusia dan menjadi kebiasaan serta tidak bertentangan dengan syara' sedangakan 'urf fasid adalah sesuatu yang telah dikenal oleh manusia dan menjadi kebiasaan tetapi bertentangan dengan syara'.68

Adapun penerimaan 'urf tersebut antara lain didasarkan pada:

64 Sapiudin Shidiq, Ushul Fiqh, cet. 1 (Jakarta: Kencana, 2011), 98.

65 Satria Effendi, Ushul Fiqh..., 79-125.

66 Sapiudin Shidiq, Ushul Figh..., 62-88.

${ }_{67}$ Satria Effendi, Ushul Fiqh..., 148-175.

68Rachmat Syafe'i, Ilmu Ushul Fiqih, cet. 4 (Bandung: Pustaka Setia, 2010), 129. 
1. Al-Qur'an surat al-A'raf ayat 19969, yang bunyinya:

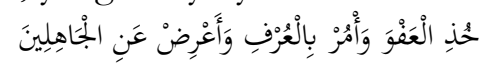

Jadilah pemaaf dan surublah orang mengerjakan yang ma'ruf (kebajikan), serta jangan pedulikan orang-orang bodoh.70

2. Athar sahabat Abdullah ibn Mas'ud, yang bunyinya:

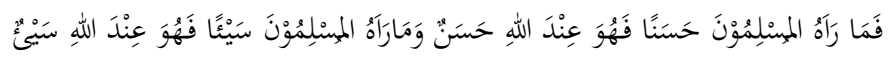

Sesuatu yang dinilai baik oleh umat Islam adalah baik disisi Allah dan sesuatu yang dinilai buruk oleh meraka adalab buruk di sisi Allah.71

3. Kaidah fikih, yang berbunyi:

Adat ("urf) menjadi pertimbangan bukum.

Adapun penggunaan adat/ urf sebagai landasan hukum tidak berlaku begitu saja, tetapi harus memenuhi beberapa persyaratan berikut:

1. Mengandung maslahah dan dapat diterima akal sehat.72

2. Berlaku umum dan merata di suatu masyarakat.

3. Tidak bertentangan dengan dalil syara'.

4. Telah berlaku sebelum adanya penetapan hukum.73

Dengan demikian, dapat disimpulkan bahwa adat dapat dijadikan landasan bagi pelaksanaan pembagian harta warisan jika memenuhi beberapa persyaratan di atas. Dalam hal ini, biasanya point ketiga (tidak bertentangan dengan dalil syara') yang sering diciderai oleh adat di suatu masyarakat, khususnya yang berhubungan dengan persoalan kewarisan. Hal ini bertentangan dengan firman Allah dalam surat al-Maidah ayat 44 yang bunyinya:

69 Amir Syarifuddin, Ushul Fiqh, jilid 2, cet. 6 (Jakarta: Kencana, 2011), 386-387.

70 Departemen Agama, Mushaf ar-Rasyid; Al-Qur'an dan Terjemahannya, cet. 1 (Jakarta: Al-Hadi Media Kreasi, 2014), 176.

71 M. Adib Hamzawi, “'Urf dalam Kompilasi Hukum Islam di Indonesia”, Inovatif, No. 2, Vol. 4 (Pebruari, 2018), 10.

72 Sapiudin Shidiq, Ushul Fiqh, cet. 1 (Jakarta: Kencana, 2011), 101-102.

73 Amir Syarifuddin, Ushul Figh..., 401-402. 
Zakiyatul Ulya: Analisis Kedudukan Adat......

$$
\begin{aligned}
& \text { فَفَ...... }
\end{aligned}
$$

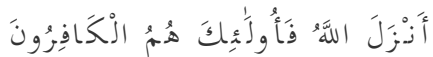

.Oleh karena itu, janganlah kamu takut kepada manusia, tetap takutlah kepada-Ku. Dan janganlah kamu menukar ayat-ayat-Ku dengan harga yang sedikit. Barangsiapa yang tidak memutuskan menurut apa yang diturunkan Allah, maka merek a termasuk orang-orang kafir. 74

Pembagian harta warisan di luar ketentuan nash di atas dapat dilakukan jika ahli waris bersepakat untuk menyelesaikan pembagian harta warisan berdasarkan suatu kesepakatan yang berbeda dengan ketentuan syara', dengan syarat semua ahli waris telah benar-benar mengetahui atas porsi/bagian dan haknya masing-masing dan tidak ahli waris lain yang dirugikan.75 $\mathrm{Hal}$ ini sesuai dengan pasal $183 \mathrm{KHI}$, yang berbunyi:

"Para ahli waris dapat bersepakat melakukan perdamaian dalam pembagian harta warisan, setelah masing-masing menyadari bagiannya."76

Pembagian berdasarkan pasal 183 semacam ini sering dilakukan oleh masyarakat Indonesia, di mana ahli waris laki-laki secara sukarela bersedia untuk menerima porsi yang sama dengan ahli waris perempuan, bahkan tidak jarang beberapa ahli waris rela melepaskan sebagian atau seluruh bagiannya untuk diberikan kepada ahli waris lain. Banyak faktor yang melatarbelakangi terjadinya kesepakatan antara ahli waris dalam hal pembagian harta warisan, antara lain karena adanya ketimpangan ekonomi atau kondisi antar ahli waris. Menurut Prof. Dr. Amir Syarifuddin, cara pembagian tersebut menyimpang dari ketentuan syara' secara materil, namun secara formal hukum waris telah selesai dijalankan sehingga telah memenuhi tuntutan syara'.77

74 Departemen Agama, Mushaf ar-Rasyid; Al-Qur'an dan Terjemahannya, cet. 1 (Jakarta: Al-Hadi Media Kreasi, 2014), 115.

75 M. Ansyari MK, Hukum Kewarisan Islam dalam Teori dan Praktik (Yogyakarta: Pustaka Pelajar, 2013), 65.

76 Kompilasi Hukum Islam.

77 M. Ansyari MK, Hukum Kewarisan Islam dalam Teori dan Praktik..., 66-67. 
Adat/'urf merupakan salah satu dalil yang tidak disepakati oleh ulama (mukbtalaf), di samping istibsan, maslabah mursalah, 'urf, istishab, shar'u man qablana, madhab al-sahabi, dan sadd al-dhari'ah. Penggunaan adat/'urf sebagai landasan hukum harus memenuhi beberapa persyaratan, yaitu: mengandung maslahah dan dapat diterima akal sehat, berlaku umum dan merata di suatu masyarakat, tidak bertentangan dengan dalil syara', dan telah berlaku sebelum adanya penetapan hukum. Adapun oleh karena, ketentuan-ketentuan nash yang dijadikan dasar kewarisan Islam bersifat qat'iyah al-dilalah dan qat'iyah al-wurud, maka harus diterima dan diamalkan secara tekstualis serta tidak terganggu oleh ijtihad para ulama. Dengan demikian, penggunaan adat dalam pembagian harta waris tidak dibenarkan karena bertentangan dengan dalil syara' (termasuk ke dalam 'urf fasid).

Akan tetapi, pembagian di luar ketentuan nash dan berdasarkan adat dapat dilakukan jika ahli waris bersepakat untuk menyelesaikan pembagian harta warisan berdasarkan suatu kesepakatan yang berbeda dengan ketentuan syara', dengan syarat semua ahli waris telah benar-benar mengetahui bagian dan haknya masing-masing serta tidak ahli waris lain yang dirugikan. Hal ini sesuai dengan pasal 183 KHI, yang berbunyi: "Para ahli waris dapat bersepakat melakukan perdamaian dalam pembagian harta warisan, setelah masing-masing menyadari bagiannya".

\section{Analisis Kedudukan Adat dalam Hukum Waris Hindu Beserta Implikasinya}

Adat atau dikenal sadacara/acara dalam agama Hindu didefinisikan sebagai kebiasaan-kebiasaan yang baik dan telah lama berlaku. Adat diakui menjadi dasar untuk penentuan hukum yang berlaku dalam memutuskan perkara (dharma mulan), di samping $\mathrm{Veda} / \mathrm{s}^{\wedge}$ ruti (sumber hukum yang patut diperdalam bagi orang yang tidak mengejar kekayaan duniawi, melainkan hanya untuk pengetahuan saja), Smriti (sumber hukum patut diperdalam bagi orang yang ingin mencapai kebahagiaan duniawi, namun tetap tidak mengabaikannya untuk kebajikan spiritual) dan priyatmana $/ s^{\wedge}$ ila (tingkah laku baik seseorang, yang menimbulkan kepuasan pada diri sendiri). 
Macam-macam sumber hukum di atas berdasarkan Sloka 12 Buku II Kitab Manava Dharmas^astra, yang berbunyi:

Vedah smrtib sadacarah svasya ca priyam atmanah, etac catur vidham | prahuh saksaddharmasya laksanam.

"Pustaka suci Veda, adat istiadat luhur, tata cara kehidupan orang suci serta kepuasan diri sendiri, dikatakan sebagai dasar empat jalam untuk merumuskan kebajikan (dharma) yang positif." 78

Dari keempat sumber hukum tersebut, Veda (vedoakblilo) menjadi sumber utama dalam mencari kebenaran, jika tidak ada dicari dalam Smrti, dapat juga didapatkan pada kedua sumber tersebut. Apabila tidak ada, baru dilihat pada acara dan terakhir pada $s^{\wedge}$ ila, sesuai dengan Sloka 6 Buku II Kitab Manava Dharmas ${ }^{\wedge}$ astra, yaitu:

Idanim \ dharma pramanamyaha: vedo "khilo dharma mulam smrtis`ile ca tadvidam, acaras ${ }^{\wedge}$ caiva sadbunam atmanastustiir eva ca.

"Seluruh pustaka suci Veda merupakan sumber pertama dari dharma, kemudian adat istiadat, lalu tingkah laku yang terpuji dari orang-orang bijak yang mendalami ajaran suci veda; juga tata cara kehidupan orang suci dan akhirnya kepuasan pribadi."'79

Kebiasaan yang berlaku bagi seseorang tersebut merupakan hukum dan juga berlaku sebagai hukum karena meliputi seluruh aspek kegiatan manusia, dengan syarat selaras dengan atmavan (mempunyai nilai bagi dirinya atau memiliki sifat-sifat yang mulia). Adapun kedudukan adat dalam hukum waris diakui dan dilegalkan pemberlakuannya berdasarkan Sloka 40 Bagian 60 Bab 7 Kitab Artas\#astra di bawah ini:

"Apapun yang menjadi hukum adat suatu daerah, varna, perusahaan atau desa, hanya sesuai dengan itu hendaknya diberlakukan hukum pewarisan." 80

78 Baghavan Bhrgu, Manava Dharmas^atra..., 33-34.

79 Ibid., 27.

80Ibid., 238. 
Berdasarkan sloka di atas, hukum adat yang berlaku di suatu daerah, varna (kaum brahmana, ksatria, vaisya dan sudra), perusahaan atau desa, diberlakukan sebagai hukum kewarisan bagi masyarakatnya.

Dengan demikian, dapat disimpulkan bahwa adat dalam agama Hindu diakui sebagai sumber hukum di samping Veda/s^ruti, Smriti, dan priyatmana $/ s^{\wedge}$ ila, dan merupakan hukum serta berlaku juga sebagai hukum karena meliputi seluruh aspek kegiatan manusia, dengan syarat selaras dengan atmavan (mempunyai nilai bagi dirinya atau memiliki sifat-sifat yang mulia). Adapun kedudukan adat dalam hukum waris diakui dan dilegalkan pemberlakuannya sebagai hukum kewarisan pada suatu daerah, varna, perusahaan atau desa berdasarkan Sloka 40 Bagian 60 Bab 7 Kitab Artas\#astra yang berbunyi: "Apapun yang menjadi hukum adat suatu daerah, varna, perusahaan atau desa, hanya sesuai dengan itu hendaknya diberlakukan hukum pewarisan".

\section{Analisis Perbandingan Kedudukan Adat Hukum Waris Islam dan Hindu Beserta Implikasinya}

Urf/adat diakui sebagai landasan hukum dengan syarat: mengandung maslahah dan dapat diterima akal sehat, berlaku umum dan merata di suatu masyarakat, tidak bertentangan dengan dalil syara', dan telah berlaku sebelum adanya penetapan hukum.81 Ketentuan-ketentuan nash yang dijadikan dasar kewarisan Islam bersifat qat'iyah al-dilalah dan qat'iyah al-wurud, maka harus diterima dan diamalkan secara tekstualis serta tidak terganggu oleh ijtihad para ulama. Oleh karenanya, penggunaan adat dalam pembagian harta waris tidak dibenarkan karena bertentangan dengan dalil syara'. Akan tetapi, pembagian di luar ketentuan nash dan berdasarkan adat tersebut dapat dilakukan jika ahli waris bersepakat untuk itu, dengan syarat semua ahli waris telah mengetahui bagian dan haknya masingmasing serta tidak ahli waris lain yang dirugikan, sebagamana pasal 183 KHI, yang berbunyi: "Para ahli waris dapat bersepakat melakukan perdamaian dalam pembagian harta warisan, setelah masing-masing menyadari bagiannya".

Adapun adat dalam agama Hindu diakui sebagai sumber hukum di samping Veda $/ \mathrm{s}^{\wedge}$ ruti, Smriti, dan priyatmana/ $\mathrm{s}^{\wedge}$ ila. Adat tersebut

81 Amir Syarifuddin, Ushul Fiqh..., 401-402. 
merupakan hukum dan juga berlaku sebagai hukum karena meliputi seluruh aspek kegiatan manusia, dengan syarat selaras dengan atmavan (mempunyai nilai bagi dirinya atau memiliki sifat-sifat yang mulia). Kedudukan adat dalam hukum waris sendiri diakui dan dilegalkan pemberlakuannya sebagai hukum kewarisan pada suatu daerah, varna, perusahaan atau desa berdasarkan Sloka 40 Bagian 60 Bab 7 Kitab Artas\#astra yang berbunyi: "Apapun yang menjadi hukum adat suatu daerah, varna, perusahaan atau desa, hanya sesuai dengan itu hendaknya diberlakukan hukum pewarisan".

Dari kedua kesimpulan di atas, dapat diketahui bahwa baik hukum Islam maupun hukum Hindu menjadikan adat sebagai sumber/landasan dalam penetapan hukum. Penggunaan adat dalam pembagian harta waris tidak dibenarkan oleh agama Islam karena bertentangan dengan dalil syara'. Hal ini karena ketentuanketentuan nash yang dijadikan dasar kewarisan Islam bersifat qat'iyah al-dilalab dan qat'iyab al-wurud, sehingga harus diterima dan diamalkan secara tekstualis dan tidak terganggu oleh ijtihad para ulama. Akan tetapi, pembagian di luar ketentuan nash dan berdasarkan adat dapat dilakukan jika ahli waris bersepakat untuk itu, dengan syarat semua ahli waris telah mengetahui bagian dan haknya masing-masing serta tidak ada ahli waris lain yang dirugikan berdasarkan pasal 183 KHI. Berbeda halnya dengan hukum Hindu, adat diakui dan dilegalkan pemberlakuannya pada suatu daerah, varna, perusahaan atau desa sebagai hukum kewarisan berdasarkan Sloka 40 Bagian 60 Bab 7 Kitab Artas\#astra.

\section{Penutup}

Adat/'urf diakui oleh hukum Islam sebagai landasan hukum dengan beberapa persyaratan tentunya. Adapun oleh karena, ketentuan-ketentuan nash yang dijadikan dasar kewarisan Islam bersifat qat'iyah al-dilalah dan qat'iyah al-wurud, maka harus diterima dan diamalkan secara tekstualis serta tidak terganggu oleh ijtihad para ulama'. Dengan demikian, penggunaan adat dalam pembagian harta waris tidak dibenarkan karena bertentangan dengan dalil syara'. Akan tetapi, pembagian di luar ketentuan nash dan berdasarkan adat dapat dilakukan dengan adanya kesepakatan ahli waris, setelah terlebih dahulu mengetahui bagiannya masing-masing serta tidak ada yang dirugikan, sebagaimana pasal 183 KHI. Adat dalam agama 
Hindu diakui sebagai sumber hukum di samping Veda/s^ruti, Smriti, dan priyatmana/ $s^{\wedge}$ ila. Adat tersebut merupakan hukum dan juga berlaku sebagai hukum karena meliputi seluruh aspek kegiatan manusia, dengan syarat selaras dengan atmavan (mempunyai nilai bagi dirinya/memiliki sifat-sifat yang mulia). Adapun kedudukan adat dalam hukum waris sendiri diakui dan dilegalkan pemberlakuannya sebagai hukum kewarisan pada suatu daerah, varna, perusahaan atau desa berdasarkan Sloka 40 Bagian 60 Bab 7 Kitab Artas\#astra.

Baik hukum Islam maupun hukum Hindu menjadikan adat sebagai sumber/landasan dalam penetapan hukum. Penggunaan adat dalam pembagian harta waris tidak dibenarkan oleh agama Islam karena bertentangan dengan dalil syara'. Ketentuan-ketentuan nash yang dijadikan dasar kewarisan Islam bersifat qat'iyah al-dilalab dan qat'iyah al-wurud, sehingga harus diamalkan secara tekstualis dan tidak terganggu oleh ijtihad para ulama. Akan tetapi, pembagian di luar ketentuan nash dan berdasarkan adat dapat dilakukan dengan adanya kesepakatan ahli waris, setelah terlebih dahulu mengetahui bagiannya masing-masing serta tidak ada ahli waris lain yang dirugikan, berdasarkan pasal 183 KHI. Berbeda halnya dengan hukum Hindu, adat diakui dan dilegalkan pemberlakuannya pada suatu daerah, varna, perusahaan atau desa sebagai hukum kewarisan berdasarkan Sloka 40 Bagian 60 Bab 7 Kitab Artas\#astra.

\section{Daftar Pustaka}

Abdurrahman. "6 Agama yang Diakui Secara Resmi oleh Negara Republik Indonesia”, dalam http://baharudinwahida.blogdetik.com/index.php/2012/1 0/25/6-agama-yang-diakui-secara-resmi-oleh-negararepublik-indonesia /, diakses pada 17 Januari 2018.

Azra, Azyumardi. et al. "Waris", Ensiklopedi Islam, Vol. 5, ed. Abdul Aziz Dahlan, et al. Jakarta: PT Ikrar Mandiriabadi, 2000.

Bachtiar, Maryati. "Hukum Waris Islam di Pandang dari Perspektif Hukum Berkeadilan Gender", Jurnal Ilmu Hukum, No. 1, Vol. 3, 2012.

Bhrgu, Baghavan, Manava Dharmasastra, terj. G. Pudja dan Tjokorda Rai Sudharta. Surabaya: Paramita, 2004. 
Darmawan. Hukum Kewarisan Islam di Indonesia. Surabaya: UIN Sunan Ampel Press, 2014.

Departemen Agama. Mushaf ar-Rasyid; Al-Qur'an dan Terjemahannya, cet. 1. Jakarta: Al-Hadi Media Kreasi, 2014.

Doi, Abdur Rahman I. Syariah The Islamic Law, terj. Zaimuddin, et al., cet. 1. Jakarta: PT. Raja Gravindo Persada, 1996.

Effendi, Satria. Ushul Fiqh, cet. 4. Jakarta: Kencana, 2012.

Hamzawi, M. Adib. "Urf dalam Kompilasi Hukum Islam di Indonesia". Inovatif, No. 2, Vol. 4, Pebruari, 2018).

Hukum Hindu. "Hukum Waris Hindu Berdasarkan Arthasastra", dalam http://hukumhindu.blog.com/2011/06/25/hukumwaris-hindu-berdasarkan-arthasastra/, diakses pada 19 Januari 2018.

Jawad (al), Ahmad 'Abd. Usul; Tlm al-Mawarith. Beirut: Dar al-Jil, 1986.

K. Lubis, Suhrawardi. et al, Hukum Waris Islam: Lengkap \& Praktik, cet. 3. Jakarta: Sinar Grafika, 2008.

Kautilya (Canakya). Artas\#astra, terj. Made Astana dan Anomdiputro. Surabaya: Paramita, 2003.

Komite Fakultas Syariah Uiniversitas Al-Azhar. Abkam al-Mawarith fi al-Fiqh al-Islami, terj. Addys Aldizar dan Fathurrahman, cet. 15. Jakarta Selatan: Senayan Abadi Publishing, 2015.

Manan, Abdul. Aneka Masalab Hukum Perdata di Indonesia, cet. 3. Jakarta: Kencana, 2012.

Moh. Muhibbin dan Abdul Wahid, Hukum Kewarisan Islam: Sebagai Pembaharuan Hukum Positif di Indonesia (Jakarta: Sinar Grafika, 2009), 62.

Naskur, "Asas-asas Hukum Kewarisan dalam Islam (Studi Analisis Pendekatan Al-Qur'an dan Al-Hadis Sebagai Sumber Hukum Islam)", Al-Syir'ah, No. 2, Vol. 10 (2012).

Niscaya Bali. "Rangkuman Kitab Manawa Dharma Sastra", dalam http:// niscayabali.net/rangkuman-kitab-manawa-dharmasastra/, diakses pada 22 Oktober 2018.

Rahman, Fatkhur. Ilmu Waris. Bandung: Al-Ma'arif, 1974.

Sabuni (al), M. 'Ali. Al-Mawarith fi ash-Shari'ati al-Islamiyah 'ala Dhaw' al-Kitab wa al-Sunnah, terj. A. M. Basamalah, cet. 1. Jakarta: Gema Insani Press, 1995. 
Sabiq, al-Sayyid. Fiqh al-Sunnah, terj, Mudzakir. Bandung: PT Alma'arif, 1987.

Saebani, Beni Ahmad. Figh Mawaris, cet. 3. Bandung Pustaka Setia, 2015.

Shidiq, Sapiudin. Ushul Figh, cet. 1. Jakarta: Kencana, 2011.

Subandi, Bambang. et. al. Studi Hukum Islam. Surabaya: IAIN SA Press, 2011.

Syafe'i, Rachmat. Ilmu Ushul Fiqih, cet. 4. Bandung: Pustaka Setia, 2010.

Syarifuddin, Amir. Hukum Kewarisan Islam. Jakarta: Kencana, 2004.

Syarifuddin, Amir. Usbul Fiqh, jilid 2, cet. 6. Jakarta: Kencana, 2011.

Usman, Suparman dan Yusuf Somawinata, Fiqih Mawaris Hukum; Kewarisan Islam. Jakarta: Gaya Media Pratama, 2002.

Wikipedia. "Agama Hindu Jawa", dalam https://id.m.wikipedia.org/wiki/Agama_Hindu_Jawa, diakses pada 19 Januari 2018.

Wikipedia; Ensiklopedi Bebas. "Hukum Indonesia", dalam http://id.wikipedia.org/wiki/Hukum_Indonesia, diakses pada 17 Januari 2018.

Wulandari, Yuni. "Studi Komparasi Tentang Ketentuan Ahli Waris dalam Hukum Islam dan Hindu". Skripsi--IAIN Sunan Ampel, Surabaya, 2012.

Zuhaili (al), Wahbah. Fiqh al-Islam wa Adillatubu, terj. Abdul Hayyie al-Kattani, et. al. Jakarta: Gema Insani, 2011.

Zuhdi, Achmad. Studi al-Qur'an, cet. 6. Surabaya: UIN Sunan Ampel Press, 2016.

Kompilasi Hukum Islam. 